\title{
POLA INTERAKSI TINGKAH LAKU INDUK \\ AYAM BETINA DAN ANAK AYAM \\ (Gallus gallus-domesticus)
}

\author{
Anwari Adi Nugroho' ${ }^{1}$, Dewi Septiana ${ }^{1}$, Siti Lestari', \\ Demo Rifwan Sugiyarto ${ }^{1}$ \\ ${ }^{1}$ Jurusan Pendidikan Biologi Universitas Veteran Bangun Nusantara Sukoharjo \\ E-mail: bio_anwary@yahoo.com
}

\begin{abstract}
The purpose of this study was to determine the behavior patterns of female hens and chicks (Gallus gallus-domesticus) in the natural environment. This type of research is descriptive exportative observing patterns of interaction between hens and chicks for 3 days in the morning, afternoon and evening. The study uses ad libitum sampling method. The tools used in the form of cameras and stationery while the materials needed are female hens and 3 chicks. Data was collected by means of observation using observation sheets and documentation tools. Data analysis using descriptive analysis techniques that describe the behavior patterns between the hen with the chick that appears during observation. the results of the study show what the behavior of the mother chickens and their offspring were interacting with. The most common behavior was to look for food, eat and drink, pay attention from the mother to the chicks, and ask for attention from the child to the mother hen. A step that was rarely seen was fighting, avoiding and sleeping.
\end{abstract}

Keywords: Behavior, Gallus gallus-domesticus, Interaction

\section{PENDAHULUAN}

\begin{abstract}
A yam kampung (Gallus gallus-domesticus) merupakan ayam yang banyak dipelihara oleh masyarakat desa (Sartika \& Iskandar, 2007). Ayam kampung merupakan istilah bagi ayam yang dipelihara tetapi tidak dibudidaya masal secara komersial. Walaupun ayam kampung merupakan ayam yang hidup dipelihara, tetapi memiliki kemampuan adaptasi yang baik khususnya di Indonesia (Iskandar, 1998). Kelebihan ayam kampung salah satunya memiliki daya adaptasi yang baik dengan cepat menyesuaikan kondisi iklim dan lingkungannya (Rasyaf, 2011). Secara histori, ayam kampung merupakan ayam yang berasal dari ayam hutan merah yang dijinakkan dan mengalami proses domestikasi, evolusi sehingga tahan terhadap cuaca dan penyakit dibandingkan dengan ayam jenis lainya (Sarwono, 2005; Crawford, 1990).

Ayam kampung di Indonesia pemeliharaanya dengan diliarkan di luar kandang dan mudah dikenali (Sulandari et al.,2007). Pemeliharaan ini sangat sederhana karena ayam mencari makan sendiri (Appleby et al., 1992). Ayam kampung termasuk dalam genus Gallus dan famili apa Phasianidae. Secara karakteristik morfologi ayam kampung memiliki ciri khas dibandingkan dengan jenis ayam lainnya yaitu corak dan warna bulunya yang beragam baik jantan maupun betina menjadi ciri khas ayam kampung.
\end{abstract}


Sebagian besar ayam kampung yang hidup di Indonesia mempunyai morfologi tubuh yang kompak dengan pertumbuhan badan relatif bagus, pertumbuhan bulunya sempurna dan variasi warna bulu juga banyak (Sarwono, 2005). Selain itu ukuran tubuhnya juga lebih kecil dibandingkan dengan ayam ras. Hal tersebut dikarenakan hasil perkawinan yang alami dan seleksi. Ayam kampung (Gallus gallus-domesticus) juga memiliki perilaku yang berbeda dengan jenis ayam lainnya. Perbedaan tersebut antara lain ayam kampung jauh lebih lincah dan aktif bergerak dibandingkan dengan ayam ras.

Ayam memiliki tingkah laku khas dalam berinteraksi dengan lingkungan maupun dengan sejenisnya. Tingkah laku ayam sebagai unggas adalah usaha ekspresi yang dilakukan unggas untuk beradaptasi terhadap perbedaan situasi internal maupun eksternal (Sunarti \& Sugiharto, 2015). Tingkah laku mempunyai fungsi tertentu berupa aksi berurutan dan aksi tunggak, aksi ini muncul karena ada respon rangsangan dari lingkungan. Ayam sebagai salah satu unggas memiiki 7 sampai 9 pola dasar tingkah laku (Curtis, 1983). Tingkah laku ayam di bagi menjadi 2 kelompok, pertama tingkah laku utama mencakup tingkah laku makan, berdiri, duduk, mengantuk (dozing), dan tidur (sleeping). Kedua tingkah laku insidental meliputi tingkah laku berjalan, minum, mematuk-matuk lantai/dinding, mengepakkan sayap dan tingkah laku agresi (berkelahi satu sama lain) (Sunarti \& Sugiharto, 2015).

Penelitian tentang produktivitas ayam sudah banyak (Savory, 1982, Noble, Dunington, \& Siegel, 1993) tetapi untuk penelitian tentang pola perilaku ayam kampung khusunya interaksi induk betina dan anak ayam masih jarang dilakukan, sehingga diperlukan penelitian tentang pola tingkah laku induk ayam betina dan anak ayam. Anak ayam yang masih kecil memiliki tingkah laku khas terutama pada saat berinteraksi dengan induk betinanya. Pada saat telur baru menetas, anak ayam akan mencari induknya dan terjadi interaksi tingkah laku antara induk ayam betina dengan anaknya. Pada penelitian ini difokuskan pada interaksi tingkah laku induk ayam betina dengan anak ayam ras ayam kampung yang dipelihara dan hidup diliarkan.

\section{METODE PENELITIAN}

Jenis penelitian adalah deskriptif eksporatif yaitu mengamati pola interaksi antara induk ayam dengan anak ayam selama 3 hari pada waktu pagi, siang, dan sore pada tanggal 09 - 11 Desember 2019. Pengamatan dilakukan di Desa Jejeran RT 01 RW 09 Toriyo, Kecamatan Bendosari, Kabupaten Sukoharjo, Jawa Tengah. Penelitian menggunakan metode ad libitum sampling. Menggunakan satu induk ayam betina dan 3 anak ayam. Metode ad libitum sampling merupakan metode penelitian yang mencatat semua aktivitas yang terlihat, baik perilaku harian maupun sosialnya. Alat yang digunakan dalam pengamatan adalah kamera dan alat tulis. Bahan yang digunakan dalam pengamatan adalah induk ayam kampung betina dan 3 anak ayam. Induk ayam betina berumur kurang lebih 7 bulan dan 3 anak ayam kurang lebih berumur 4 minggu. Data kualitatif pada penelitian ini diperoleh dari hasil pengamatan mengenai tingkah laku induk ayam dengan anaknya. Data diperoleh setelah melakukan pengamatan langsung. Analisis data menggunakan teknik analisis deskriptif yaitu mendeskripsikan pola perilaku antara induk ayam betina dengan anak ayam yang muncul selama pengamatan. Prosedur penelitian bisa dilihat pada gambar 1. 


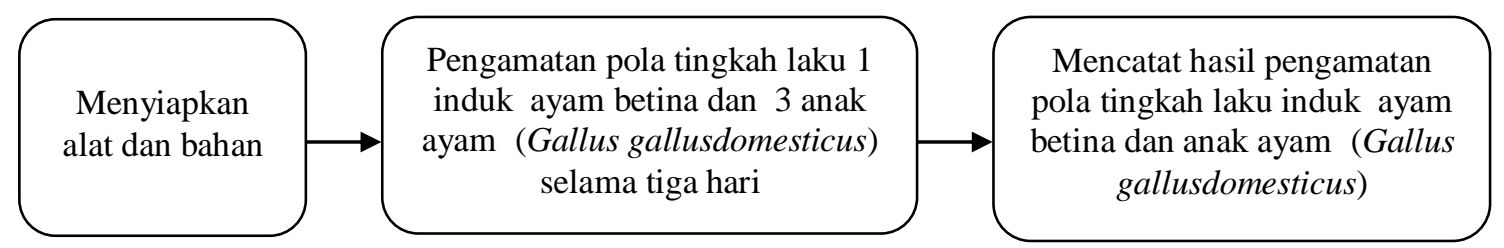

Gambar 1. Prosedur penelitian Pola Tingkah Laku Induk Ayam Betina dan Anak Ayam (Gallus gallus-domesticus)

Penjelasan Gambar 1 sebagai berikut: 1) Menyiapkan alat dan bahan dalam penelitian seperti 1 induk ayam betina dan 3 anak ayam. Alat yang dibutuhkan antara lain alat dokumentasi dan alat tulis, buku referensi. Bahan yang dibutuhkan antara lain 1 induk ayam betina dan 3 anak ayam. 2) Melakukan pengamatan selama 3 hari dengan masing-masing hari dilakukan pegamatan selama 3 kali yaitu pagi hari (07.00-08.00 WIB), siang hari (12.00 - 13.00 WIB) dan sore hari (17.00-18.00 WIB). Pola perilaku induk ayam betina dengan anak ayam yang diamati berupa tingkah laku: a). mencari makanan (feed seeking/foraging). b) makan dan minum (ingestive). c) pencarian tempat berteduh (shelter seeking). d) berselisih-bertengkar-menghindar (agonistic). e) memberi perhatian dari induk ke anak (epimeleticatau care giving). f) minta perhatian dari anak ke induk (et epimeletic atau care soliciting). g) bermain (play). h) tidur (sleeping). i) mematuk-matuk bulu (feather pecking). j) berjalan (walking/locomotory behaviour). 4) Mencatat hasil pegamatan. (Sunarti \& Sugiharto, 2015)

Data diambil dengan cara pengamatan langsung menggunakan lembar observasi, catatan pengamatan, serta alat dokumentasi. Hasil data yang sudah terkumpul kemudian dianalisis menggunakan teknik analisis deskriptif yaitu mendeskripsikan perilakuperilaku yang muncul selama pengamatan.

\section{HASIL DAN PEMBAHASAN}

Ayam kampung merupakan ayam yang berasal dari ayam hutan merah yang dijinakkan dan mengalami proses domestikasi (Sarwono, 2005; Crawford, 1990) dan proses tersebut dimulai setidaknya 8000 tahun yang lalu (Eriksson et al., 2008). Sebagian besar ayam kampung yang hidup di Indonesia mempunyai morfologi tubuh yang kompak dengan pertumbuhan badan relatif bagus, pertumbuhan bulunya sempurna dan variasi warna bulu juga banyak (Sarwono, 2005). Ayam kampung yang ada saat ini (Gallus gallusdomesticus) berasal dari ayam hutan (Gallus varius) di Asia Tenggara. Ayam kampung diprediksi berasal dari pulau Jawa, tetapi saat ini ayam hutan sudah tersebar sampai ke Pulau Nusa Tenggara (Rasyaf, 2011). Ayam kampung termasuk dalam genus Gallus dan famili apa Phasianidae.

\begin{tabular}{ll}
\multicolumn{2}{c}{ Klasifikasi Ilmiah (Suprijatna et al, } \\
Kingdom & : Animalia \\
Phylum & : Chordata \\
Subphylum & : Vertebrata \\
Class & : Aves \\
Subclass & : Neornithes \\
Ordo & : Galliformes \\
Genus & : Gallus \\
Spesies & $:$ Gallus gallus-domesticus
\end{tabular}


Ayam kampung (Gallus gallus-domesticus) memiliki perilaku yang berbeda dengan jenis ayam lainnya. Anak ayam yang masih kecil memiliki tingkah laku khas terutama pada saat berinteraksi dengan induk betinanya. Penelitian tingkah laku induk ayam betina dengan anak ayam telah dilakukan dan mendapatkan hasil seperti pada Tabel 1 berikut.

Tabel 1. Hasil Pengamatan Pola Tingkah Laku Induk Ayam Betina dan Anak Ayam (Gallus gallus-domesticus)

\begin{tabular}{|c|c|c|c|c|c|c|c|c|c|c|c|}
\hline \multirow{2}{*}{ Hari ke } & \multirow{2}{*}{ Waktu } & \multicolumn{10}{|c|}{ Tingkah Laku } \\
\hline & & 1 & 2 & 3 & 4 & 5 & 6 & 7 & 8 & 9 & 10 \\
\hline \multirow{3}{*}{1} & Pagi & $\sqrt{ }$ & $\sqrt{ }$ & & & $\sqrt{1}$ & $\sqrt{ }$ & & & & $\sqrt{ }$ \\
\hline & Siang & $\sqrt{ }$ & $\sqrt{ }$ & $\sqrt{ }$ & $\sqrt{ }$ & $\sqrt{ }$ & $\sqrt{ }$ & $\sqrt{ }$ & & $\sqrt{ }$ & $\sqrt{ }$ \\
\hline & Sore & $\sqrt{ }$ & $\sqrt{ }$ & $\sqrt{ }$ & & $\sqrt{ }$ & $\sqrt{ }$ & & $\sqrt{ }$ & & $\sqrt{ }$ \\
\hline \multirow{3}{*}{2} & Pagi & $\sqrt{ }$ & $\sqrt{ }$ & & & $\sqrt{ }$ & $\sqrt{ }$ & $\sqrt{ }$ & & & $\sqrt{ }$ \\
\hline & Siang & $\sqrt{ }$ & $\sqrt{ }$ & & & $\sqrt{ }$ & $\sqrt{ }$ & & & $\sqrt{ }$ & $\sqrt{ }$ \\
\hline & Sore & $\sqrt{ }$ & $\sqrt{ }$ & $\sqrt{ }$ & & $\sqrt{ }$ & $\sqrt{ }$ & & & $\sqrt{ }$ & \\
\hline \multirow{3}{*}{3} & Pagi & $\sqrt{ }$ & $\sqrt{ }$ & & & $\sqrt{ }$ & $\sqrt{ }$ & $\sqrt{ }$ & & & $\sqrt{ }$ \\
\hline & Siang & $\sqrt{ }$ & $\sqrt{ }$ & $\sqrt{ }$ & $\sqrt{ }$ & $\sqrt{ }$ & $\sqrt{ }$ & & & $\sqrt{ }$ & \\
\hline & Sore & $\sqrt{ }$ & $\sqrt{ }$ & $\sqrt{ }$ & & $\sqrt{ }$ & $\sqrt{ }$ & $\sqrt{ }$ & & & $\sqrt{ }$ \\
\hline
\end{tabular}

Keterangan: 1. mencari makanan. 2. makan dan minum. 3. pencarian tempat berteduh. 4. berselisih-bertengkar-menghindar.

5. memberi perhatian dari induk ke anak. 6. minta perhatian dari anak ke induk. 7. bermain. 8. tidur. 9. mematuk-matuk bulu. 10. berjalan.

Setelah melakukan pengamatan selama 3 hari, tingkah laku induk ayam kampung betina dan anak ayam yang paling sering dilakukan yaitu mencari makanan. Pada saat mencari makan, ayam terlihat memilih makanan dengan cara mencoker-coker makanan yang ada di depannya. Setelah itu, ayam mulai memakan makanan sesuai dengan makannya. Collias \& Collias (1967) menyatakan unggas domestik akan mematuk tumbuh-tumbuhan dan tanah dengan paruh dan cakar untuk mencari makanan. Pada pengamatan, induk betina juga terlihat seperti mengajari anakannya dalam mematuk makanan disertai dengan mencoker-coker tanah dan mengeluarkan suara yang khas. Pada saat itu, semua anak ayam mengikuti cara induk ayam dalam mematuk. Sunarti \& Sugiharto, (2015) menjelaskan bahwa tingkah laku mencari makan baik induk betina dan anaknya yang dipelihara dalam sistem ekstensif (umbaran), dan pada kondisi normal, ayam dapat memerlukan $90 \%$ waktunya pada siang hari.

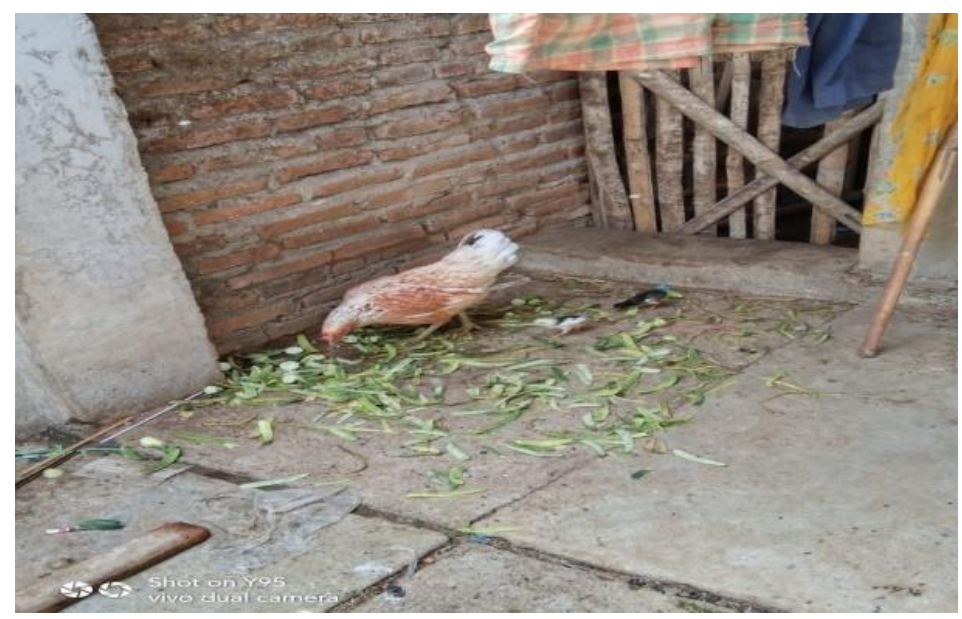

Gambar 2. Induk ayam dan anak ayam saat mencari makanan 
Ayam secara alami memiliki kemampuan untuk memilih pakan. Ayam lebih suka pakan dengan warna yang cerah dan ukuran partikel tertentu menggunakan paruhnya. Pada pengamatan, terjadi perbedaan pada induk betina dslam memilih makanan. Induk ayam lebih sering memilih makanan/ pakan yang berukuran sedikit lebih besar jika dibandingkan dengan makanan yang dipilih oleh anak ayam. Hal tersebut seperti dijelaskan oleh Sunarti \& Sugiharto, (2015) menjelaskan bahwa anak ayam yang baru menetas lebih memilih pakan crumble/remahan dan induk ayam dewasa memilih pakan pellet dan butiran. Induk ayam maupun anakannya dalam makan tidak tergantung pada hewan lain. Sesuai penjelasan Appleby (1992) bahwa ayam mencari makan sendiri dengan menggunakan paruhnya. Ayam menggunakan paruh mereka sebagai sarana utama untuk menyentuh dan merasakan, juga untuk mengambil dan memanipulasi objek termasuk makanan. Paruh berfungsi untuk aktivitas seperti merapikan, bersarang, dan pertahanan (Lunam, 2005).

Tingkah laku yang sering dilakukan selanjutnya adalah makan dan minum. Induk ayam betina maupun anak ayam memiliki tingkah laku yang sama dalam makan dan minum. Induk ayam betina dan anak ayam lebih sering makan dan minum di luar kandang mereka waupun dalam kandang tersedia pakan dan minum.

Tingkah laku yang sering dilakukan selanjutnya yaitu memberi perhatian dari induk ke anak. Pada pengamatan bentuk proses perhatian induk ayam betina terhadap anaknya yaitu dengan mengepakkan sayapnya ketika anakanya diganggu oleh kelinci. Selain dengan mengepakkan sayap, induk ayam juga mengeluarkan suara khasnya yang keras dan diarahkan ke kelinci. Sementara anak ayam mendekat ke induknya untuk mendapat perlindungan. Induk ayam betina cenderung tidak lari menjauhi kelinci tetapi lebih kepada mengusirnya. Ayam secara naluri tidak bisa membedakan predator dan tidak, sehingga setiap ada hewan lain yang mendekati, ayam cenderung mengusir bahkan berusaha untuk menyerang. Sunarti \& Sugiharto (2015) menjelaskan bahwa pendengaran ayam sangat baik yang dapat berguna pada saat ada predator atau ancaman maka ayam akan mengeluarkan suara khasnya. Ayam kampung yang merupakan hasil domestifikasi dari ayam hutan, memiliki sedikit keberanian (rasa takut yang berkurang) jika dibandingkan dengan ayam hutan (Appleby et al., 1992).

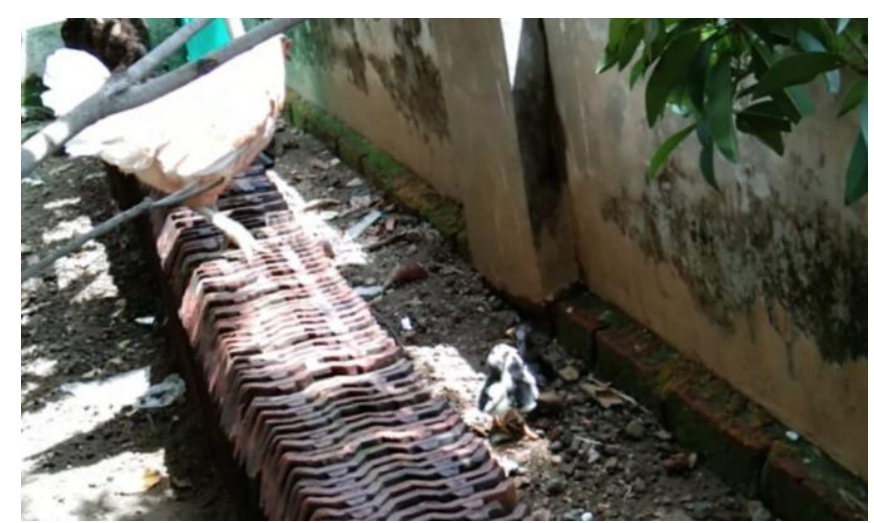

Gambar 3. Induk ayam betina memberi perhatian anak saat diganggu oleh kelinci

Tingkah laku minta perhatian dari anak ke induk juga selalu dilakukan. Tingkah laku minta perhatian anak ke induk dalam pengamatan adalah ketika anak ayam tertinggal dengan induk ayam betina maka anak ayam akan minta perhatian dengan mengeluarkan suara yang khas dan sedikit keras. Ketika anak ayam sudah melihat 
induknya, anak ayam langsung berlari menuju induk. Anak ayam yang tertinggal dikarenakan anak ayam yang kurang memperhatikan induknya saat mencari makan. Collias (1987) menjelaskan bahwa anak ayam menampilkan belasan jenis panggilan kepada induknya.

Tingkah laku berjalan sering dilakukan ayam baik induk mapun anakannya. Pada pengamatan tingkah laku berjalan sering ditemukan karena ayam merupakan hewan yang aktif pada siang hari dan bukan hewan nokturnal, sehingga sepanjang hari kecuali malam, ayam kampung aktif bergerak untuk mencari makan.

Setelah melakukan pengamatan selama 3 hari tingkah laku induk ayam kampung betina dan anak ayam yang jarang dilakukan yaitu tingkah laku mencari tempat berteduh Pada pengamatan tingkah laku ini jarang ditemukan karena pada saat pengamatan lingkungan tidak terlalu panas atau hujan sehingga induk ayam betina dan anak ayam lebih sering berjalan untuk mencari makan. Sunarti \& Sugiharto (2015) menyatakan bahwa unggas mencari tempat berteduh apabila dalam keadaan ingin beristirahat, hujan, atau serangan dari predator. Tingkah laku berselisih- bertengkarmenghindar, dalam tiga hari pengamatan tingkah laku ini hanya ditemukan tiga kali pada pengamatan pertama waktu siang hari yaitu diserang oleh kelinci dan pada pengamatan ketiga waktu pagi dan siang hari oleh kelinci dan angsa. Tingkah laku ini jarang ditemukan karena karena ayam termasuk hewan yang bergerombol apabila berselisih biasanya berkaitan dengan melindungi anaknya atau untuk merebutkan makanan.

Tingkah laku bermain jarang dilakukan selama pengamatan karena ayam kampung menggunakan waktunya sepanjang hari untuk mencari makanan. Induk ayam betina terlihat seperti mematuk matuk tubuh anakannya secara pelan. Tingkah laku tersebut seperti induk ayam yang mengajak bermain anakannya. Tingkah laku tidur jarang dilakukan karena pengmatan dilakukan pada pagi hari sampai dengan sore hari, sedangkan ayam biasanya tidur pada malam hari. Tingkah laku tidur termasuk tingkah laku utama karena tingkah laku tidur digunakan untuk beristirahat. Pada pengamatan tingkah laku mematuk - matuk bulu jarang dilakukan karena induk ayam dan anakannya sepanjang hari aktif mencari makan.

Sedangkan ditinjau dari waktu pengamatan, maka pola tingkah laku induk ayam betina dengan anakannya dapat diihat pada Gambar 4.

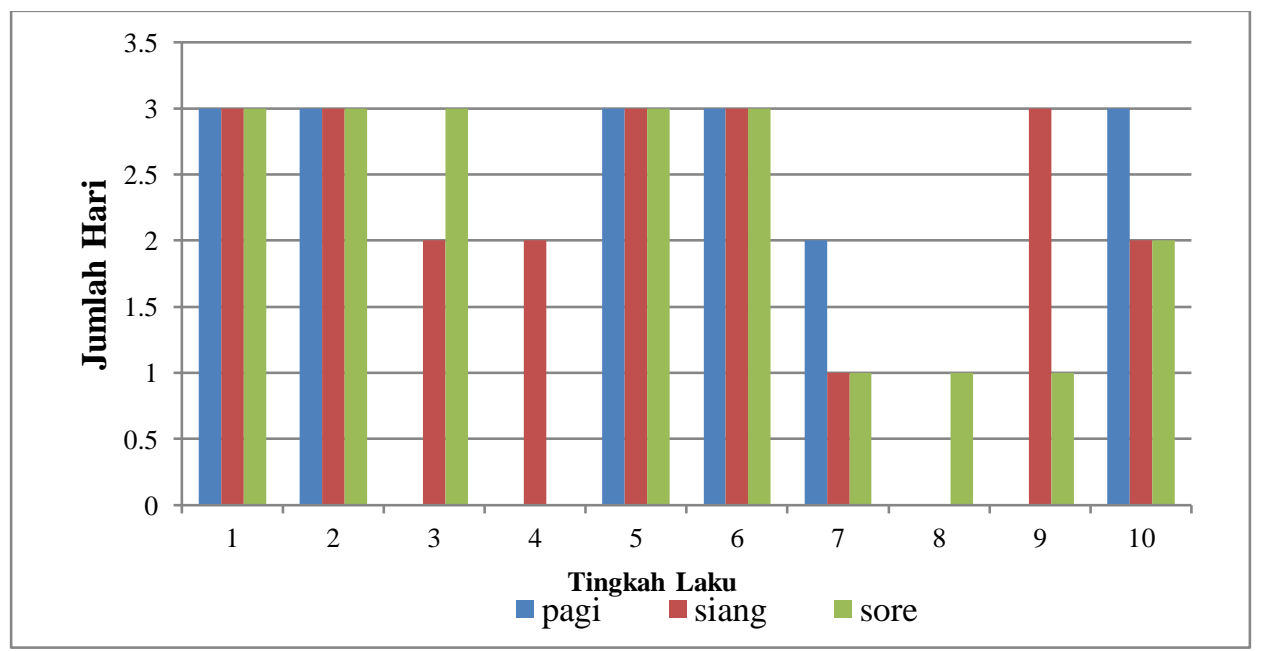

Gambar 4. Pola Tingkah Laku Induk Ayam Betina dan Anakannya ditinjau dari Waktu Aktivitas (Pagi, Siang dan Sore) 


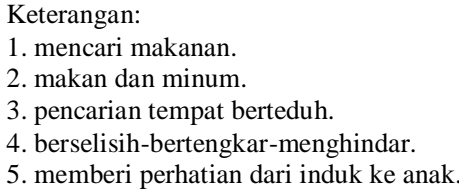

Berdasarkan Gambar 4 dapat diketahui bahwa tingkah laku mencari makan, makan dan minum, memberi perhatian dari induk ke anak, minta perhatian dari anak ke induk dilakukan oleh induk maupun anakannya setiap hai (3 hari) pada pagi, siang dan sore hari. Sementara tingkah laku berselisih-bertengkar-menghindar hanya dilakukan pada siang hari selama 2 hari. Tingkah laku tidur hanya dilakukan sehari dan pada sore hari. Tingkah laku nomor 1, 2, 5 dan 6 selalu dilakukan oleh induk ayam betina dan anakannya setiap hari karena salah satunya adanya interaksi antara induk dan anak ayam. Induk selalu mengajari anaknya dalam mencari makan dan makan. Kemudian induk ayam juga sering melakukan aktivitas untuk mencari perhatian kepada anakannya begitu pula sebaliknya.

\section{KESIMPULAN}

Berdasarkan hasil penelitian dapat disimpulkan bahwa terjadi interaksi tingkah laku induk betina ayam kampung dan anakannya. Tingkah laku yang paling sering dilakukan (dominan) yaitu tingkah laku mencari makanan, makan dan minum, memberi perhatian dari induk ke anak, dan minta perhatian dari anak ke induk. Ketiga tingkah laku tersebut dilakukan oleh induk ayam betina dan anakannya dalam beraktivitas dan berinteraksi. Tingkah laku tersebut juga dilakukan sepanjang hari, pagi siang dan sore. Sedangkah tingkah laku yang jarang terlihat yaitu berselisih-bertengkar-menghindar dan tidur. Tingkah laku tersebut jarang terlihat karena ayam kampung yang hidup diliarkan sedikit dijumpai predator dan pengamatan dilakukan ada pagi siang dan sore hari.

\section{DAFTAR PUSTAKA}

Appleby, M. C., Hughes, B. O., \& Elson, H. A. (1992). Poultry production systems. Behaviour, management and welfare. $\mathrm{CAB}$ international.

Collias, N. E. (1987). The vocal repertoire of the red junglefowl: a spectrographic classification and the code of communication. The Condor, 89(3), 510-524.

Collias, N. E., \& Collias, E. C. (1967). A field study of the red jungle fowl in north-central India. The Condor, 69(4), 360-386.

Crawford, R.D. (1990). Poultry Biology : Origin and History of Poultry Species. In : Poultry Breeding and Genetics (Ed. Crawford, R. D.). Elsevier Science Publishing Company Amsterdam and New York.

Curtis, S. E. (1983). Environmental management in animal agriculture. Iowa State University Press.

Eriksson, J., Larson, G., Gunnarsson, U., Bed'Hom, B., Tixier-Boichard, M., Strömstedt, L. \& Jensen, P. (2008). Identification of the yellow skin gene reveals a hybrid origin of the domestic chicken. PLoS genetics, 4(2).

Iskandar, J. (1989). Jenis burung yang umum di Indonesia. Djambatan.

Lunam, C. A. (2005). The anatomy and innervation of the chicken beak: effects of trimming and retrimming. Poultry welfare issues-beak trimming (ed. PC Glatz), 51-68. 
$96 \_J u r n a l$ Teknosains, Volume 14, Nomor 1, Januari-Juni 2020, hlm. 89-96

Noble, D. O., Dunnington, E. A., \& Siegel, P. B. (1993). Ingestive behavior and growth when chicks from lines differing in feed consumption are reared separately or intermingled. Applied Animal Behaviour Science, 35(4), 359-368.

Rasyaf, I. M. (2011). Beternak ayam kampung. Penebar Swadaya Grup.

Sartika, T., \& Iskandar, S. (2007). Mengenal Plasma Nutfah Ayam Indonesia. Balai Penelitian Ternak, Bogor, 140 .

Sarwono, B. (2005). Beternak Ayam Buras Pedaging dan Petelur. Edisi Revisi. Penebar Swadaya, Jakarta.

Savory, C. J. (1982). Effects of broiler companions on early performance of turkeys. British Poultry Science, 23(2), 81-88.

Sulandari, S., Zein, M. S. A., Paryanti, S., Sartika, T., Astuti, M., Widjastuti, T. \& Garnida, D. (2007). Sumberdaya genetik ayam lokal Indonesia. Keanekaragaman Sumber Daya Hayati Ayam Lokal Indonesia: Manfaat dan Potensi, 45-104.

Sunarti, D., \& Sugiharto, S. (2015). Kesejahteraan dan Metode Penelitian Tingkah Laku Unggas.

Suprijatna, E. U. Atmomarsono, \& K. Ruhyat. (2005). Ilmu Dasar Ternak Unggas. Cetakan 1. Penebar Swadaya. Jakarta. 